\title{
FOOD SECURITY AND GMOS
}

\author{
Schlett András PhD ${ }^{1}$, Beke Judit PhD \\ ${ }^{1}$ Pázmány Péter Chatolic University \\ E-mail: schlett.andras@jak.ppke.hu
}

\begin{abstract}
This study deals with potential food security impacts of GM technology. GMOs are a debated issue in the current Transatlantic Trade and Investment Partnership (TTIP) trade negotiations, lending particular significance to our topic. Patents have been issued on gene sequences that allow biotech giants the exclusive right to profit from these varieties. To protect the specific genes, in addition to the desired properties seed infertility is also encoded. As a consequence, farmers who are no longer able to produce their own seeds become completely defenceless against multinational producers. In this way the supply of staple foods, like food grains, will be monopolized by transatlantic companies, giving them control over the markets, making selfsufficiency of nations and local producers impossible.
\end{abstract}

Keywords: second green revolution, GM seeds, TTIP, TRIPS, food security, JEL classification: Q180

\section{Introduction}

The population of the planet is increasing rapidly and almost one in ten will suffer from undernutrition. To feed the hungry millions sustainable agricultural production must increase significantly. The crops developed during the Green Revolution were high yield varieties of grain that required expensive inputs. The new Green Revolution aims at maintaining food selfsufficiency and food sovereignty. It emphasizes improved farm management and information systems to benefit farmers bypassed by the original green revolution (FAO). Agriculture will depend on genetically modified crops in the hope of overcoming the chronic food shortages. The GM crop movement did enormous good but also presented significant adverse consequences and prompted controversy. Patents issued on GM seeds allow biotech giants the exclusive right to profit from these seeds and as a consequence seeds will have to be bought rather than saved making the farmers vulnerable. GMOs are a debated issue in the current Transatlantic Trade and Investment Partnership (TTIP) trade negotiations as well.

\section{The second green revolution: release from dependence and new dependencies}

In the mid-20th century the green revolution has forever transformed the way agriculture is conducted. Over the years many significant changes have occurred that we now associate with industrial agriculture. The first green revolution established a global agriculture that bore fruit in the 1960's and 1970's, but it created unwanted side effects and eventually moved from boom to dust. In the countries of the Arabian Peninsula for instance, as a result of a massive restructuring agriculture drastically improved and the kingdoms became self-sufficient and were successful in raising the domestic output of important crops through the introduction of new varieties and irrigation. Due to the overuse of water the water tables fell and the kingdoms suffered from aquifer depletion. 
Re-cultivation takes a long time, moreover the green revolution spurred its share of unintended negative consequences that no one had ever dared to think of: the serious environmental impacts, unintended consequences in water use, a drastic reduction in biodiversity, irreversible soil degradation, etc.

At the turn of the century, there was a shift to a second green revolution. Agriculture turned to genetically modified crops as the best hope for overcoming the chronic food deficit as was predicted by Malthus 200 years ago. The GM crop movement did enormous good but also presented significant adverse consequences. Not only sciences e.g. medical sciences, economics, sociology, environmental sciences, but producers and consumers as well warn that the effects are uncertain.

There are strong scientific arguments in support of and in opposition to agricultural biotechnology innovations. Supporters emphasize the potential gains from the production of GM crops that is to increase food production in countries facing serious food shortages and malnutrition. The currently employed technology and the relatively low yields cannot effectively meet the needs of the world's growing population, therefore the production of GM crops has the potential to feed the world. Technological development in agriculture and genetic engineering is developing, the revolutionary new crop varieties spread at a rapid pace and produce high yields. Between 2000 and 2012, the production of GM crops increased from 10 million hectares to 70 million hectares in developing countries, while in developed countries it increased from 30 million hectares to 70 million hectares (European Risk Summit, 2013). Opponents however argue that for moral reasons and for economic interest we must not interfere in the natural order. They believe that the long-term effects of genetically engineered crops are unknown. The expanded production and use of GMOs is opposed to sustainability since it facilitates the production of monocultures, intensive production technologies and is highly uniform. Instead of using GMOs that have serious health risks, job creation, the reduction of luxury food consumption and a land reform could bring more results (Beke, 2014).

Genetic engineering raises serious food security issues, as food sovereignty is threatened in certain countries. Food sovereignty is the right of countries to determine their own food production and consumption and to build reserves of healthy and nutritious food to ensure food security. As Vandana Shiva (2001, p. 69) writes in the book titled Protect Or Plunder? Understanding Intellectual Property Rights "seed, for the farmer, is not merely a source of future plants/food; it is the storage place of culture, of history. Seed is the ultimate symbol of food security".

The Agreement on Trade-Related Aspects of Intellectual Property Rights (TRIPS agreement), which is administered by the WTO, raises concerns since it enables large foreign corporations to obtain patent control of the local, small scale production and distribution of seeds (Barker, 2007).

\section{The Transatlantic Trade and Investment Partnership (TTIP)}

The Multilateral Agreement on Investment (MAI) was a draft agreement that bore a strong resemblance to the Transatlantic Trade and Investment Partnership (TTIP). The draft aimed at liberalizing foreign investments and it guaranteed corporations unconditional rights without any regard for national laws and a right to sue governments if their interests were threatened. 
After pressure from developing countries the negotiations that took place secretly from 1995 until 1997 failed in 1998. Although the MAI negotiations failed, similar trade accords like the Transatlantic Trade and Investment Partnership (TTIP) or the Trans-Pacific Partnership (TPP) are planned. The main aim of these accords is to promote trade liberalization by decreasing the remaining trade barriers and the obstacles to foreign investments. This means that the partners had to adopt a trade strategy and had to open their markets without any restrictions to the global market for trade and investments. According to the draft agreement, if a partner country restricts trade or investments, then foreign companies have the right to sue the government and they will abide by the decision of an independent international court, just as the MAI draft prescribed earlier.

The Transatlantic Trade and Investment Partnership agreement has been negotiated between the US and the EU since 2013 June. As opposed to the former free trade agreements, the TTIP does not aim at the reduction of import duties (between the EU and the US trade barriers and duties are already relatively low) but it aims at removing non-tariff barriers on trade and investments.

The TTIP negotiations face opposition since the accusations of secrecy. Another criticism is that the negotiations are not over the prosperity of the partners but the deal is about providing powerful industrial lobbies with an opportunity to modify the current European trade and investment regulations (Baker, 2013).

Another important component of the agreement is the provision of the Investor-State Dispute Settlement (ISDS) mechanism. Under this mechanism foreign investors can sue governments and seek compensation if their profits or investment potentials are affected. This mechanism would allow certain biotech giants to sue governments if, for instance, they ban genetically modified crop varieties. The ISDS mechanism allows large foreign corporations to appeal to "offshore tribunals" operating in secret to defend their interests against governments. The political sociologist Colin Crouch argued that Europe is witnessing a transition towards a "postdemocratic" society. The driving force is that international agreements protect the interest of multinational corporations against society (Crouch, 2013).

The TTIPS agreement might completely transform the environment, public health and consumer protection policies in the European Union. It is well known that health regulation standards in the US are less strict, furthermore the US did not sign any of the world's major environmental conventions like the Basel, Kyoto or Stockholm conventions. Pressure to drop the zero tolerance policy regarding GM foods and seeds, to allow GM crops in Europe and to ban the mandatory labelling of GM foods and ingredients comes from the biotech industry.

\section{Food sovereignty}

Countries that support the new Green Revolution aim at maintaining food self-sufficiency. It is important to note however that the production of GM crops is secret, the products are not labelled, are protected by patents and the production is profit oriented. Patents on GM crops provide the biotech giants control over farmers which places them in a vulnerable position (Darvas, 2009).

Large companies that develop GM seeds purchase rivalling smaller seed producing companies with the aim of increasing the prices of seeds and taking control over farmers. 
Farmers are forced to buy patented GM seeds that are significantly more expensive than conventional seeds. "GMO Cops" (or "GMO Mafias") hunt down farmers to ensure that seeds are not planted without paying the company licencing fees (Natural Society, 2012). The farmers' freedom will decrease, traditional seeds will slowly disappear and GM seeds will displace and destroy diversity. Patented GM seeds threaten seed sovereignty and thus food sovereignty since the farmers, who traditionally save their own seeds for the next season, do not have their own seeds anymore. There are judgements made in favour of seed giants like Monsanto that is serious about ensuring the protection of the patented seeds. Farmers who "illegally" save seeds are often forced to submit to Monsanto sanctions, e.g. they have to pay compensation or their farms are supervised by Monsanto for 5 years (Berlan, 2000, Móra, 2012).

A new chapter in the history of agricultural genetics began when the so called Terminator seeds were developed and patented by the US Department of Agriculture and a private company, Delta and PineLand. With the use of the Genetic Use Restriction Technologies (GURTs), seeds - patented as suicide seeds - are engineered and genetically modified so that they destroy the plant reproduction capabilities. The seeds will germinate, start to grow, produce average yields but eventually the plant will develop sterile seeds. In 1998 Monsanto, the biotech giant purchased Delta and PineLand together with the terminator technology (Engdahl, 2006).

In agriculture the information age has arrived, Monsanto and other biotech giants own the advanced agricultural technologies to produce new genetically engineered crop varieties. Monsanto positioned itself to become like Microsoft supplying "operating systems" to run these new generation of crops (Pollan, 1998).

Since the first GMO plantings in 1996, more than 1.8 billion hectares have been cultivated which is an almost 100-fold increase during the period. In 2014 GM crops were planted in 28 countries of the world and the number of biotech companies quadrupled from 6 to 28 . According to the International Service for the Acquisition of Agri-Biotech Applications (ISAAA), the agro-biotechnology agency, the top countries planting biotech crops are the US, Brazil, Argentina, India, Canada (Table 1.). In Europe 5 countries (Spain, Portugal, Czech Republic, Romania and Slovakia) grow GM crops on appx. 1500 hectares (ISAAA Brief, 2014).

Table 1.: Top GM crop producing countries in 2014 (million hectares)

\begin{tabular}{|l|c|c|c|}
\hline Country & $\begin{array}{c}\text { Cultivated area } \\
\text { (million } \\
\text { hectares) }\end{array}$ & $\begin{array}{c}\text { Share of world } \\
\text { total }\end{array}$ & $\begin{array}{c}\text { Types of crops } \\
\text { (S = Soybean, M= Maize, } \mathbf{R}= \\
\text { Rapeseed, C=Cotton, SB=sugar } \\
\text { beet) }\end{array}$ \\
\hline US & 73.1 & $40 \%$ & $\mathrm{~S}, \mathrm{M}, \mathrm{C}, \mathrm{R}$, squash, papaya \\
\hline Brazil & 40.3 & $22 \%$ & $\mathrm{~S}, \mathrm{M}, \mathrm{C}$ \\
\hline Argentina & 24.3 & $13.3 \%$ & $\mathrm{~S}, \mathrm{M}, \mathrm{C}$ \\
\hline India & 11.6 & $6.3 \%$ & $\mathrm{C}$ \\
\hline Canada & 11.6 & $6.3 \%$ & $\mathrm{~S}, \mathrm{M}, \mathrm{R}, \mathrm{SB}$ \\
\hline
\end{tabular}

Source: ISAAA Brief, 2014

Table 1. and Figure 1. show that GM crops are commercially planted in developed and developing countries as well, the US and Brazil being the major producers of GMOs.

The choice of GMOs varies: soybeans, maize and cotton are the main crops under commercial cultivation. In 2014, 90.7 million hectares of biotech soybean, 184 million hectares of maize 
and 37 million hectares of biotech cotton were planted (ISAAA Brief, 2014). Figure 2. depicts the year-to-year growth of the GM cultivation areas (million hectares) between 1996 and 2014.

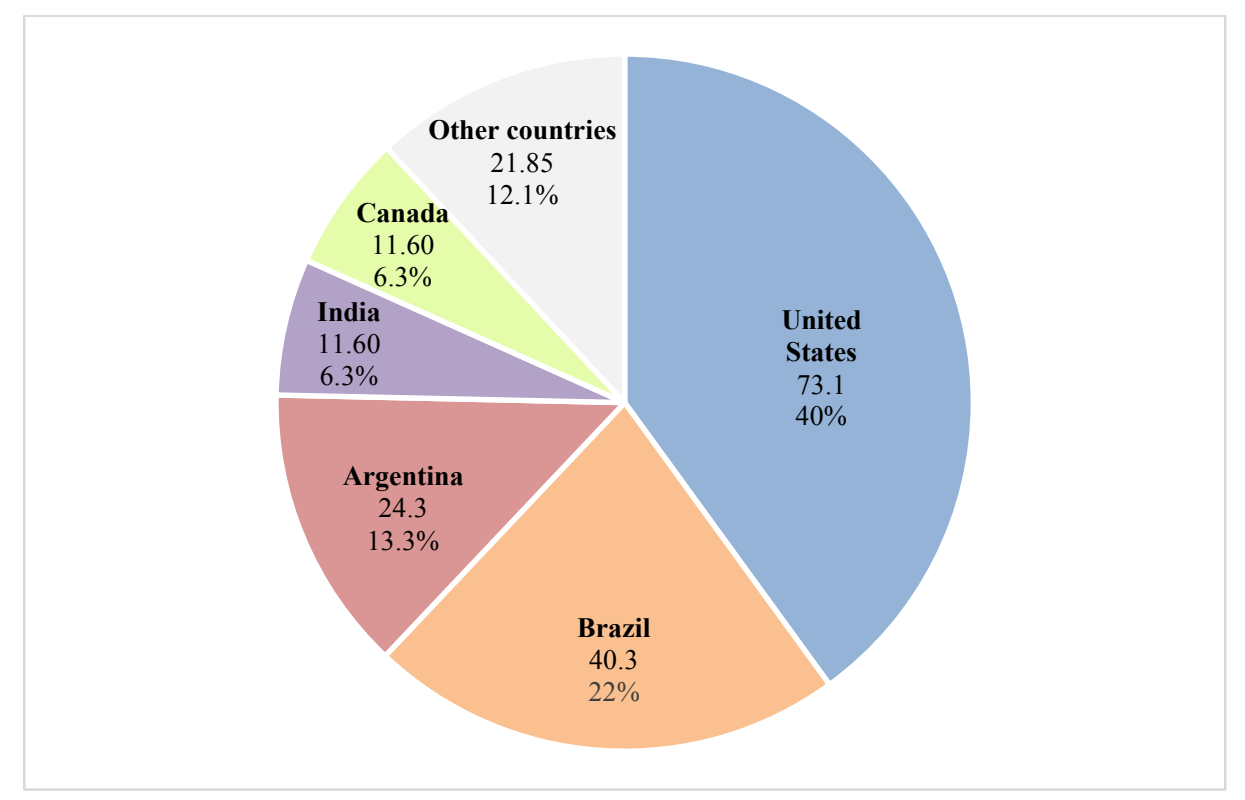

Figure 1.: Top GM crop producing countries in 2014 (million hectares)

Source: Self compilation based on ISAAA Brief 2014

As can be seen in Figure 2., the production of GM crops started in the 1996, and in the past 20 years cultivation has increased globally but the increase has slightly slowed down in the past 5 years.

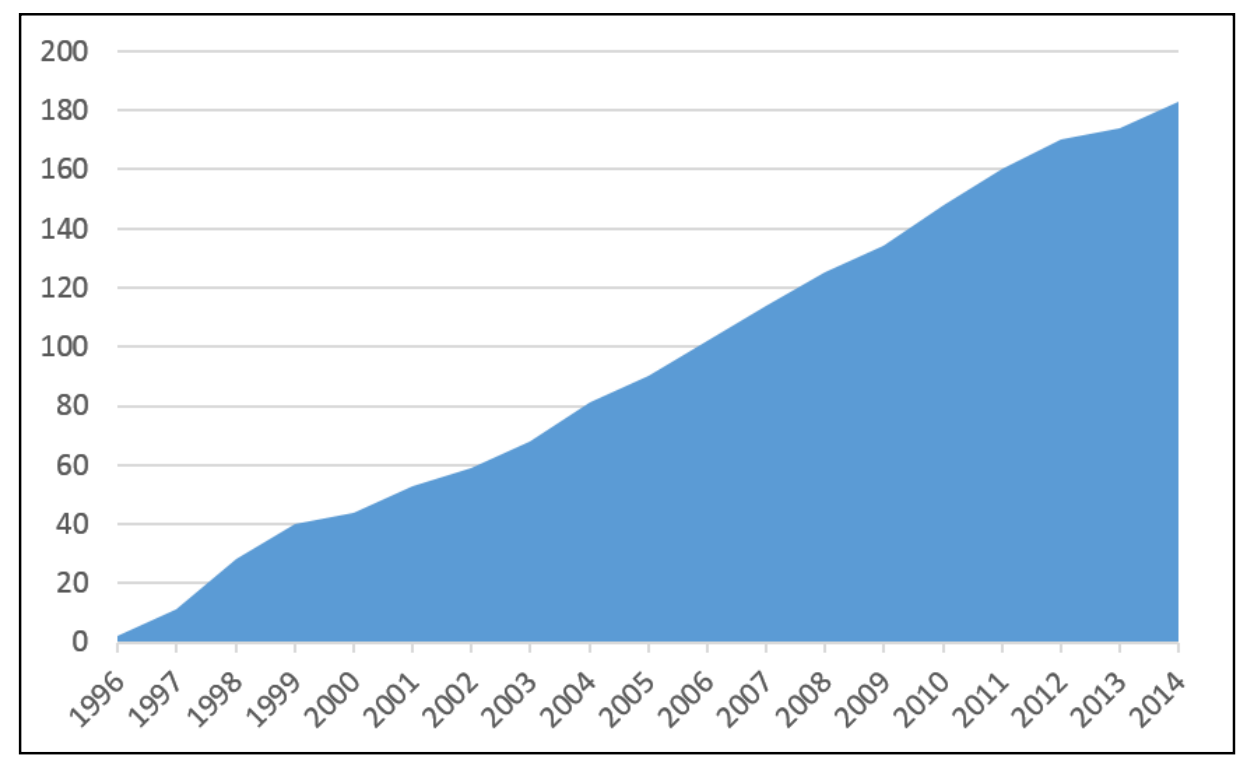

Figure 2.: Cultivation areas with genetically modified plants, $1996-2014$, in millions of Source: Self compilation based on EuropaBio hectares.

The use of gene technology will further concentrate power in the global food market. The production and distribution of seeds would be monopolized by giant multinational seed companies and farmers would become overly independent on them. As a result of this 
"Enclosure Movement" an integrated global monoculture would appear (Bello, 2008). With the spread of the integrated global monoculture small-scale farming methods decline rapidly. As a result of the disappearing peasant culture hundreds of millions of people would become vulnerable and exploited wage workers in industrial farms or would become unemployed, and social tensions are increasing.

\section{European countries: challenges and solutions}

Weather to authorise or restrict/ban GMOs is increasingly in the centre of the debates. Some member states would authorise GMOs and would tolerate conventional or organic seeds with GMO content. They are in favour of the authorisation of animal feed containing GM ingredients and they argue that the EU has not been self-sufficient in producing animal feed - the EU is dependent mainly on protein plant imports - that come from GM plants. Other member states would completely ban GMOs on their territory (Map 1.). These countries would apply and even tighten the precautionary principle and they consider strict scientific risk assessment inevitable (Homoki, 2015). Map 1. and Table 2. depicts that in Europe only five countries authorised the cultivation of GM crops (orange), whereas some member states can decide on the limitation or ban of GM crop production.

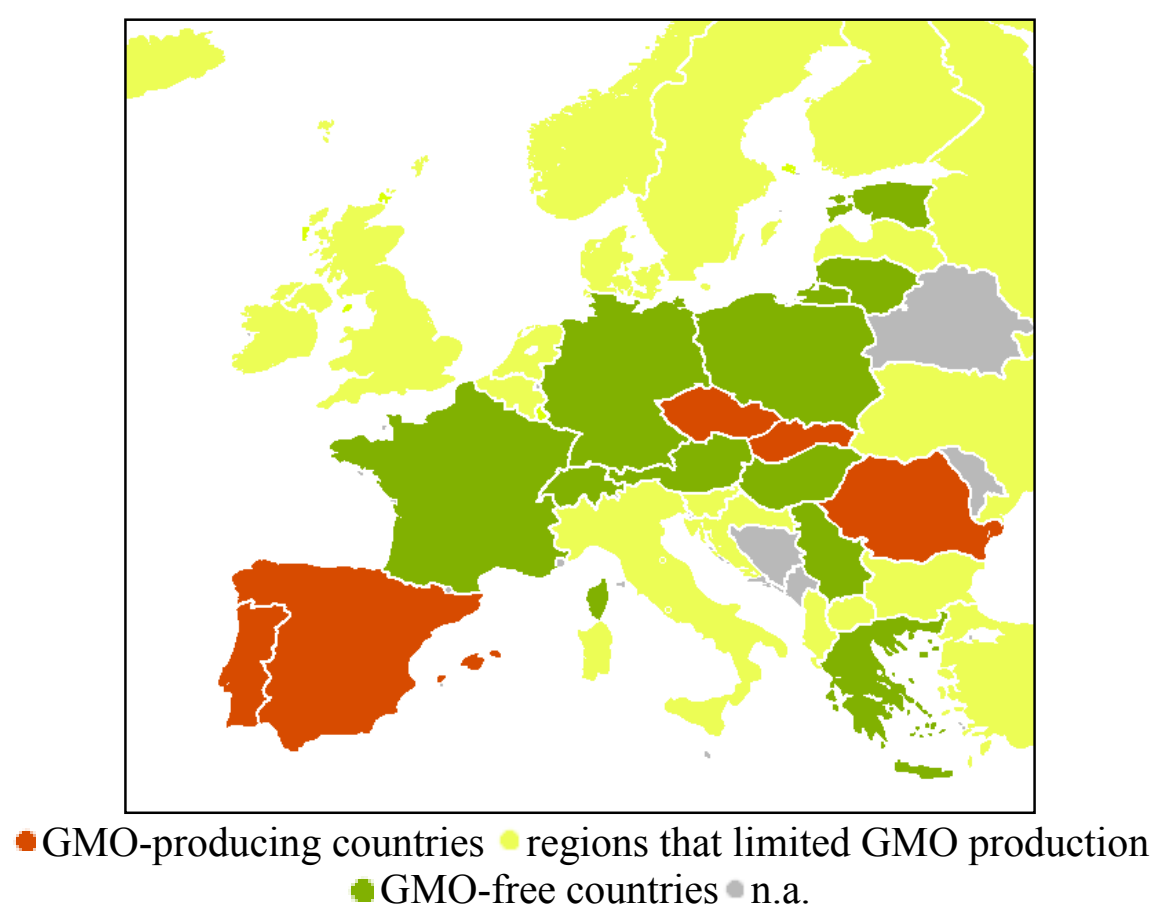

Map 1.: GMO cultivation in Europe in 2014

Source: Self compilation based on GMO-free Europe

Table 2. GM crops in the $\mathbf{E U}$ in 2013

\begin{tabular}{|l|l|}
\hline Country & Cultivated area (hectares) \\
\hline Spain & 137,000 \\
\hline
\end{tabular}




\begin{tabular}{|l|l|}
\hline Portugal & 8,171 \\
\cline { 2 - 3 } Czech Republic & 2,800 \\
\hline Romania & 834 \\
\hline Slovakia & 100 \\
\hline
\end{tabular}

Source: GMO Compass, 2013.

The US and the WTO forced Europe to introduce more permissive rules on GMOs, however the Council of the European Union gave more possibilities to Member States to limit or ban the cultivation of GMOs that are authorised at EU level. It is odd since it was agriculture that had a common subsidy system and a common policy. The new approach will keep the centralised authorisation system, however the cultivation of GMOs will be authorised in two phases. It is doubtful whether the member states can maintain their GMO-free status while GMO agriculture is expanding in the European Union (Horváthy, 2015).

\section{Concluding remarks}

European agriculture faces multiple challenges because of the spread of GM crops therefore cooperation and a multidisciplinary approach is needed. Hungary is one of the few countries in the world where the production of GMOs is banned and the requirement of a GMO free agriculture is determined by the Fundamental Law of Hungary (Article XX/2).

GM crops escaping in the environment represent a serious problem. GMO contamination may result from pollen drift that creates inevitable contamination in the neighbouring GM-free crops, from seed impurities, from insect-borne cross-pollination, from inadequate harvest and handling practices or anywhere in the food supply chain. Such contamination may remain unknown because the identification of GM content is only possible by laboratory testing and to find the source of contamination can be hard or even impossible.

The most comprehensive study on pollen drift conducted by researchers at the University of Bremen proves that the pollen of GM corn can travel further than expected. The European Food Safety Authority (EFSA) reconsidered its previous safety assessments of GM crops (Homoki, 2015).

To preserve the purity of seeds seems to be impossible. Within a short period of time the production of GM corn will increase significantly in Europe. GM contamination is reported in traditional or organic products sold in the EU and farmers and distributors have a lot of fear about the widespread contamination. Traditional or even organic products sold in the EU might contain GMOs that are either authorised in other countries or that are not authorised anywhere in the world. As a consequence, the cultivation of GM crops that did good in feeding the world presented significant adverse consequences and prompted controversy.

\section{References}

1. Alexandratos, N. and Bruinsma, J. (2011): World agriculture towards 2030/2050: the 2012 revision. ESA Working paper [online], No. 12-03. Rome, FAO. Agricultural Development Economics Division. Available at: http://www.fao.org/docrep/016/ap106e/ap106e.pdf [Accessed: 10 July, 2011]

2. Ángyán, J. (2001): Az európai agrármodell, a magyar útkeresés és a környezetgazdálkodás. Budapest: Agroinform Kiadóház pp. 106-107 
3. Barker, D. (2007): The Rise and Predictable Fall of Globalized Industrial Agriculture International Forum on Globalization (22 January, 2007, San Francisco) [online]. Available at: http://ifg.org/v2/wp-content/uploads/2014/05/ag-report.pdf [Accessed: 8 January, 2015]

4. Baker, D. (2013): The US-EU trade deal: don't buy the hype. Guardian [online], 15 July, 2013. Available at: http://www.theguardian.com/commentisfree/2013/jul/15/us-trade-dealwith-europe-hype [Accessed: 3 April, 2015]

5. Beke, J. (2014): Egy felmelegedő világ élelmezése - mert enni nem csak hosszú távon, de naponta kell. (Feeding the world on a warming planet - because everybody on Earth has to eat, and not only on the long run but each and every day). EU Working Papers, Budapest Manuscript.

6. Bello, W. (2008): Manufacturing a food crisis. The Nation [online]. Available at: http://www.thenation.com/article/manufacturing-food-crisis [Accessed: 2 July, 2008]

7. Berlan, J. P. and Lewontin, R. C. (2000): Genetikaipar: az élő szervezet kisajátítása. Eszmélet folyóirat, 45: spring.

8. Crouch, C. (2013): Post-Democracy: the challenge for Europe. Queries, The European Progressive Magazine [online], 17 June, 2013. Available at: http://www.queriesfeps.eu/post-democracy-the-challenge-for-europe/ [Accessed: 1 April, 2015]

9. Darvas, B. (2009): Biokultúra [online], 2/2009. Available at: http://www.biokontroll.hu/cms/ [Accessed: 28 March, 2015]

10. Engdahl, F. W. (2006): Geopolitics - geoeconomics [online]. Available at: http://www.engdahl.oilgeopolitics.net/GMO/Monsanto/monsanto.html [Accessed: 27 January, 2015]

11. EuropaBio (2013): Launch of new website: Fundación Amata - 15 years of Bt Maize in Spain. [online]. Available at: http://www.europabio.org/news/launch-new-website-fundacin-antama-15-years-bt-maize-spain [Accessed: 16 April, 2015]

12. European Risk Summit (2013): Errant GM wheat strain reopens debate about safety of biotech crops [online]. Available at: http://www.euractiv.com/specialreport-risk-hazardpolicy/errant-gmo-wheat-strain-reopens-news-528398 [Accessed: 10 June, 2014]

13. FAO (2009): How to feed the world in 2050 [online]. Available at: http://www.fao.org/fileadmin/templates/wsfs/docs/expert paper/How to Feed the Worl $\mathrm{d}$ in 2050.pdf [Accessed: 10 April 2015]

14. Giddings L., Stepp M. and Caine, M. (2012): Feeding the planet in a warming world. Building resilient agriculture through innovation. ITIF [online], April 2013. Available at: http://www2.itif.org/2013-feeding-planet-warming-world.pdf [Accessed: 10 May, 2013]

15. GMO Compass (2013): GM plants in the EU in 2013 - Green gene technology in the European Union: Spain, Portugal and hardly anything else [online]. Available at: http://www.gmocompass.org/eng/agri biotechnology/gmo planting/392.gm maize_cultivation_europe 2 013.html [Accessed: 3 March, 2015]

16. GMO-free Europe (2015): GMO-FREE Regions by Country [online]. Available at: http://www.gmo-free-regions.org/gmo-free-regions.html [Accessed: 9 April, 2015] (map1)

17. Gucciardi, A. (2012): GMO Cops: Biotech Giant Hires Former Cops to 'Enforce Patents'. Natural Society [online]. Available at: http://naturalsociety.com/gmo-cops-biotech-gianthires-former-cops-to-enforce-patents/\#ixzz3WuJ8NeN5 [Accessed: 30 March, 2015]

18. Homoki, H. (2014): Az európai GMO-engedélyezés jelene és problémái. Környezetvédelmi és Vízügyi Minisztérium, Budapest Kerekasztal füzetek, 22: 20. Available at: http://www.mtvsz.hu/dynamic/gmo_kerekasztal26.pdf [Accessed: 28 March, 2015] 
19. Horváthy, B. (2015): Az uniós GMO-engedélyezési rendszer reformja-Növekvő tagállami mozgástér? MTA TK JTI [online]. Available at: http://jog.tk.mta.hu/blog/2015/03/azunios-gmo-engedelyezesi-rendszer-reformja [Accessed: 15 March, 2015]

20. ISAAA Brief (2014): ISAAA Brief 49-2014: Top Ten Facts [online]. Available at: http://www.isaaa.org/resources/publications/briefs/49/toptenfacts/default.asp [Accessed: 12 April, 2015]

21. Magyarország Alaptörvénye (The Fundamental Law of Hungary) XX. Article (2) Paragraph [online]. Available at: http://www.mfa.gov.hu/NR/rdonlyres/8204FB28-BF22-481A-9426D2761D10EC7C/0/FUNDAMENTALLAWOFHUNGARYmostrecentversion01102013.p df [Accessed: 12 April, 2015]

22. Móra, V. (2012): Genetikai beavatkozások és életszabadalmak - Géntechnológia a mezőgazdaságban [online]. Available at: http://www.foek.hu/gaia/gaia370a.htm [Accessed: 26 March, 2012]

23. Pollan, M. (1998): Playing God in the Garden. The New York Times Magazine [online]. Available at: http://michaelpollan.com/articles-archive/playing-god-in-the-garden/ [Accessed: 18 October, 1998]

24. Shiva, V. (2001): Protect Or Plunder? Understanding Intellectual Property Rights. Zed Books. (Global Issues Series). 